\title{
MILOŠ TALIGA:
}

\section{Kritický racionalizmus a metóda falzifikácie}

\section{Banská Bystrica: Signis 2019, 79 s.}

Na slovenskom filozofickom „trhu“ sa objavila knižka Kritický racionalizmus a metóda falzifikácie od autora Miloša Taligu. Na prvý pohl'ad by sa mohlo zdat', že téma, ktorej sa venuje, bola už vel'akrát „prežutá“ a t’ažko sa k nej dá povedat' niečo zásadne nové. Autor si však takýto ciel' nekladie. Vychádza z presvedčenia, že „metóda falzifikácie je - v kontraste $\mathrm{k}$ metódam verifikácie a konfirmácie - skutočnou metódou, ktorá sa bežne použiva v empirických vedách“(s. 5). Toto presvedčenie ho vedie k obhajobe falzifikacionizmu ako stále plodnej a životaschopnej metódy vedeckého poznávania. Svoju obhajobu stavia najmä na precíznom formulovaní vlastnej logiky tejto metódy, ako aj jej širšieho filozofického pozadia, aby z takto vybudovanej pozície mohol odrážat' rôzne pretrvávajúce námietky proti falzifikacionizmu, ktoré považuje za chybné. Taliga tým jasne dáva najavo, že názory o možnej zastaranosti či prekonanosti metódy falzifikácie sú podl'a neho nesprávne a táto metóda ani v súčasnosti ešte nepovedala posledné slovo.

Kl'účové je zasadenie idey falzifikacionizmu do rámca Popperovej koncepcie kritického racionalizmu. Až z tohto hl'adiska sa detailne ukazujú povaha a možnosti tejto metódy a viaceré námietky proti nej javia ako prázdne. Podla Taligu atraktivita tohto prístupu tkvie v tom, že „Popperov kritický racionalizmus prirodzeným spôsobom spája svoj náhl'ad na metodologický arzenál, ktorý majú k dispozícii vedci, s rozborom rozumových schopností, ktorými disponuje každý premýšlajúci človek“ (s. 6). Kritický racionalizmus sa tak netýka len filozofie vedy, ale preniká aj do rozličných iných oblastí, končiac až sociálnymi a politickými otázkami, ktorým sa Popper takisto venoval. Pre Taligu je preto nevyhnutné ešte pred vysvetlením metódy falzifikácie ako takej najprv dostatočne vyložit' kritický racionalizmus, čomu vyhradzuje takmer polovicu svojej knihy.

Kritický racionalizmus približuje didakticky prostredníctvom troch asymetrií: asymetrie medzi verifikáciou a falzifikáciou (§ 1.1), asymetrie medzi akceptáciou a odmietnutím (§ 1.2) a asymetrie medzi zdôvodňovaním a kritizovaním (§ 1.3). Vo vzt’ahu k prvej spomenutej asymetrii Popper razí názor, že singulárne testovacie tvrdenia nikdy nemôžu 
verifikovat' univerzálne tvrdenie, teda dokázat' ho ako pravdivé, ale môžu ho len falzifikovat', čiže vyvrátit'. Ide o logickú tézu, ktorá vychádza z predpokladu, že univerzálne tvrdenia môžu byt' exemplifikované potenciálne nekonečným počtom singulárnych prípadov. Druhá asymetria je spätá s princípom empirizmu. Hovorí, že testovanie nejakého tvrdenia môže viest' len $\mathrm{k}$ jeho odmietnutiu, nie $\mathrm{k}$ jeho prijatiu, ked'že $\mathrm{v}$ istom zmysle už bolo prijaté na testovanie. Ani úspešne otestované tvrdenie totiž nemení svoj objektívny obsah, ale azda len zvyšuje svoju prestíž vo vedeckej obci, čo však z hl'adiska jeho nároku na pravdu nie je relevantné. Napokon tretia asymetria - tá má epistemický charakter. Popper chápe pokusy o zdôvodnenie vedeckých teórií ako pokusy o predloženie pozitívnych dôvodov v prospech ich pravdivosti, či aspoň pravdepodobnosti. To však podla neho nemožno dosiahnut'. Môžeme len navzájom komparovat' rozličné teórie a predkladat' kritické argumenty vedúce $\mathrm{k}$ preferencii niektorej z nich. No obstátie teórie v takej kritike nie je ekvivalentné s jej zdôvodnením, teda s potvrdením jej pravdivosti; preferencia teórie je vždy hypotetická a otvorená voči d’alšej kritike. Tento záver je v súlade s charakteristickým popperovským predpokladom, pri ktorom sa Taliga bližšie pristavuje v d'alších dvoch podkapitolách (§ 1.4 a $§ 1.5)$, že vzhl'adom na rozličné logické a epistemické obmedzenia nie je $\mathrm{v}$ silách vedy dosahovat' pravdivé, respektíve čoraz pravdepodobnejšie teórie. Jediné, čo vede ostáva, je systematické vylučovanie nepravdivých teórií.

Tým prechádza $\mathrm{k}$ téme druhej kapitoly, $\mathrm{v}$ ktorej dostáva priestor sama metóda falzifikácie. Autor najprv vyjasňuje problém empirickej bázy, teda statusu základných tvrdení, ktoré vstupujú do empirického testovania (§ 2.1). Kritizuje snahy o zdôvodnenie týchto tvrdení a prízvukuje, že aj základné tvrdenia sú už presiaknuté teóriami, a teda sú rovnako hypotetické - nezdôvodnené. Ak sú však základné tvrdenia nezdôvodnené, tak aj záver o falzifikácii nejakej teórie, ktorý sa pomocou nich dosiahne, musí byt' rovnako nezdôvodnený. Taliga tomuto dôsledku neprotirečí; naopak, tvrdí, že aj falzifikácie ako také majú hypotetický, teda nezdôvodnený charakter. Za rozhodujúcu považuje otázku ich pravdivosti, nie zdôvodnenia ( $(2.2)$. V d’alších častiach sa vyrovnáva s najvážnejšími námietkami proti falzifikacionizmu. Duhem-Quinova téza a problém nedourčenosti poukazujú na to, že pri úspešnej falzifikácii nemožno jednoznačne určit', ktorá čast' testovaného systému (vrátane rôznych teoretických predpokladov a pomocných hypotéz) bola vlastne vyvrátená (§ 2.3). Taliga opät reaguje, že celý problém vzniká v súvislosti s požiadavkou zdôvodnenia. Uznáva, že nemáme pozitívne dôvody v prospech konkrétnej odpovede na daný problém, no upozorňuje, že tento fakt nijako nediskredituje funkčnost' samej falzifikácie, čiže odvodenia nepravdivosti teórie. Podobné riešenie ponúka autor aj vo vzt’ahu k chybe predpokladania záveru a paradoxu inferencie, ktoré vyvolávajú podozrenie, že v procese falzifikácie je jej záver už obsiahnutý v premisách, respektíve že pravdivost' záveru je už vopred predpokladaná (§ 2.4). Tieto podozrenia by boli legitímne, keby išlo o procesy zdôvodňovania - no ked' si pripomenieme, že falzifikácia je 
hypotetická, teda nevznáša nárok na zdôvodnenie svojich záverov, tak aj tieto námietky sa rozplývajú. V záverečnej podkapitole (§ 2.5) Taliga zosúlad'uje metodologický negativizmus, podl'a ktorého vedecké metódy „neslúžia na produkciu ani konštitúciu vedeckých poznatkov (hypotéz), ale na ich vyrad’ovanie“ (s. 61), s objektivizmom, čiže názorom, že podstatnejší je obsah teórií ako postoj vedcov $\mathrm{k}$ nim.

Nebudem systematicky hodnotit' koncepciu, ktorú Miloš Taliga vo svojej monografii obhajuje (na to by priestor recenzie rozhodne nestačil), ale chcem sa polemicky zamerat' na jeden motív, ktorý sa vinie takmer celou knihou a považujem ho za problematický. Ide o odmietanie zdôvodňovania. Ako bolo spomenuté, zdôvodnenie je v knihe stotožňované s predkladaním pozitívnych dôvodov v prospech pravdivosti respektíve pravdepodobnosti tvrdení. Pokial' ide o vedecké teórie, definitívny dôkaz ich pravdivosti sa nedá podat'; možno nájst' len prípadný dôkaz ich nepravdivosti. Preto je definované zdôvodnenie odmietané ako nemožné. Namiesto zdôvodňovania je presadzovaná kritika, teda predkladanie kritických argumentov. Tie v protiklade k zdôvodneniu slúžia na odhal'ovanie nepravdivosti teórií, vd'aka čomu sa dajú komparatívne oddel'ovat' „lepšie“ teórie od „horších“.

No s paušálnym odmietnutím zdôvodnenia to asi nebude také jednoduché. Naznačuje to aj terminológia, ktorú používa sám Popper v jednom z citovaných úryvkov: „Často môžeme poskytnút dôvody [kurzíva - M. N.], prečo považujeme jednu teóriu za lepšiu ako inú. Spočívajú v zdôrazňovaní, že (a ako) jedna teória dosial' obstála v kritike lepšie ako iná. Budem tieto dôvody nazývat' kritickými dôvodmi, aby som ich odlíšil od pozitivnych dôvodov poskytnutých so zámerom zdôvodnenia teórie“ (s. 18 - 19). Zdá sa, že Popper hovorí o rozličných druhoch zdôvodňovania. „Pozitívne zdôvodnenie“, ktoré asociuje s predkladaním dôkazov pravdivosti, v prípade vedeckých teórií nepripúšt’a. Avšak „kritické zdôvodnenie“, teda vyhodnocovanie teórií z hl’adiska ich doterajšieho obstátia v kritike, zdanlivo považuje za integrálnu súčast’ vedeckého diskurzu.

To tvorí jadro problému, na ktorý chcem poukázat'. V knižke je pojem zdôvodnenia celkom odmietnutý, zatial' čo sa ponúka aj taká interpretácia, podl’a ktorej by sme zamýšl’ali (a azda aj sám Popper zamýšl'al) odmietnut' len jeden konkrétny druh zdôvodnenia. Zdôvodnenie je totiž široký pojem. Môžeme ho chápat' ako indikátor pravdivosti, no v tomto zmysle ho Popper nepripúšt’a. Môžeme ho však chápat' aj ako to, na základe čoho aktuálne preferujeme jeden názor pred druhým, hoci bez záruky, že daný názor je skutočne pravdivý. Mám za to, že zdôvodnenie $\mathrm{v}$ tomto zmysle neraz používame v prirodzenom jazyku i v odborných diskurzoch. Ved' pokial' ide o vedecké teórie, tak predsa môžeme povedat', že nejakú teóriu momentálne prijímame preto, lebo dostupné dôvody zatial' najväčšmi svedčia v jej prospech (a v neprospech konkurenčných teórií). Odvolanie na ",ôvody“ tu zjavne neašpiruje na to, aby dokazovalo danú teóriu ako pravdivú. Skôr tu ide o akési slabšie, komparatívne odôvodnenie našej preferencie, ktoré nápadne 
pripomína Popperove „kritické dôvody“. Teda nie každé zdôvodnenie je definitívnym zdôvodnením. Obávam sa, že prehliadanie tohto faktu môže viest’ $\mathrm{k}$ vážnym nedorozumeniam vzhl'adom na reálnu jazykovú prax.

Keby sme naznačené úvahy chceli dat' (predbežne) do nejakého koncepčného rámca, tak by sme zdôvodnenie mohli rozdelit' na silné a slabé. Silné zdôvodnenie by bolo zdôvodnenie pravdivosti respektíve pravdepodobnosti určitého tvrdenia. Naproti tomu slabé zdôvodnenie by sa dalo chápat' ako zdôvodnenie preferencie nejakého presvedčenia, názoru, postoja a pod. Opakujem, v tomto prípade bez nároku na (definitívnu) pravdivost'. O slabom zdôvodnení by sme mohli hovorit' v situáciách, ked' (ešte) nevieme definitívne potvrdit', či je nejaký náš názor správny, ale zároveň máme rôzne dôvody, indície a motívy, pre ktoré sa k nemu zatial' prikláňame. Iste, raz sa môžu ukázat' ako nepravdivé, ale v danom momente to môžu by najlepšie dôvody, aké práve máme k dispozícii. Mat' názory v súlade s najlepšími dostupnými dôvodmi je koniec-koncov požiadavkou racionality a kritického myslenia.

Celý spor je napokon možno len terminologický. Jeden povie „kritizovanie“, druhý povie „slabé zdôvodnenie“, a pritom obaja možno myslia na čosi príbuzné. Lenže nejde o maličkost'. Taliga robí terminologické rozhodnutie, ked” termín „kritické dôvody“, ktorý používa Popper, nahrádza údajne priliehavejším termínom „kritické argumenty“ (s. 21). Nazdáva sa, že táto terminologická zmena je v lepšom súlade s literou Popperovho prístupu. Práve na pozadí uvedenej zmeny možno pozorovat' presadenie zúženého chápania zdôvodnenia iba v zmysle predkladanie pozitívnych „dôkazov“" pravdivosti. No vybrat' si jeden úzky (a problematický) význam určitého výrazu a na základe neho sa snažit' zdiskreditovat' daný výraz ako taký sa javí ako krok, pre ktorý v texte chýba dostatočné zdôvodnenie (sic!). Analogicky, keby sme spravodlivost' chápali ako právo silnejšieho a poukázali na nedostatky tohto konkrétneho chápania, tak tvrdenie, že sociálna filozofia sa preto celkovo musí zaobíst' bez pojmu spravodlivosti, by nevyzeralo ako najštastnejšie riešenie.

V širšom kontexte môžeme povedat', že spôsob, akým je tu metóda falzifikácie traktovaná, problematizuje jej epistemické aspekty. Z popperovského pohl'adu platí, že hoci sa veda nezaobíde bez pojmu pravdy, tak túto pravdu nedosahuje priamo. K pravde sa môže približovat' len nepriamo, pomocou postupného identifikovania a „oddel'ovania“ nepravdivých výrokov (s. 27). Lenže ak spolu s Taligom odmietneme všetky druhy dôvodov a zdôvodňovania, tak sa vynára otázka, podl'a čoho môžu vedci vlastne vediet', že úspešne vykonali nejakú falzifikáciu, a tak našli nepravdivý výrok? Autor trvá na tom, že celý tento proces nemá so zdôvodňovaním nič spoločné. Tvrdí, že nezdôvodnené sú tak základné tvrdenia, teda empirické dáta, ktoré vstupujú do procesu testovania teórie, ako aj jeho výsledok, čiže odvodenie nepravdivosti testovanej teórie. Zdôrazňuje, že celá falzifikácia je len hypotetická: ,... hypotetický status má aj samotná falzifikácia teórie T vedci nemôžu zdôvodnit' záver, ku ktorému ich doviedla falzifikácia teórie $\mathrm{T}$, čiže verdikt, 
že T je nepravdivou teóriou“ (s. 45). To zrejme znamená, že vedci nemajú žiadne dobré dôvody mysliet' si, že v rámci falzifikácie prihliadali na relevantné dáta, že správne vykonali odvodenie dôsledkov a že tak pravdivo vyvrátili testovanú teóriu. No Taliga to nevníma ako problém. Podla neho nie je rozhodujúca otázka zdôvodnenia, ale otázka faktickej pravdivosti tvrdení. Aj v prípade, že vedci nemajú žiadne dobré dôvody na svoje závery, tieto závery môžu byt' objektívne pravdivé. Preto v jeho chápaní neprítomnost' zdôvodnenia nijako neohrozuje funkčnost' samej falzifikácie: „Hypotetický status (...) neznamená nesprávnost falzifikácie teórie T" (tamže), pretože aj nezdôvodnené tvrdenia môžu byt' objektívne pravdivé, a tak môžu objektívne falzifikovat' testovanú teóriu.

V predchádzajúcej vete je z môjho pohl'adu kl'účovou uvedená modalita: nezdôvodnené tvrdenia môžu byt' pravdivé (a môžu falzifikovat' teóriu). Iste, môžu, ale aj nemusia. Možno sa vedci opierajú o nesprávne dáta a odvodzujú z nich nepravdivé dôsledky - to nevieme. To je asi pointa tvrdenia, že celá falzifikácia je hypotetická. No to opät platí len za predpokladu, ked’ zdôvodnenie chápeme úzko a v silnom zmysle. Nazdávam sa, že vedci si nevymýšl’ajú svoje postupy a závery bezdôvodne, ale že ich predsa opierajú o nejaké dôvody. Tak isto sa nazdávam, že sami vedci by rozhodne nesúhlasili s názorom, že ich výsledky sú nezdôvodnené. Pravdepodobne by uznali, že dôvody, ktoré reálne používajú, často ešte nie sú zárukou pravdivosti ich názorov, no možno by pripomenuli, že sa riadia najlepšími dôvodmi, aké sú pre nich momentálne dostupné. Tým chcem znova poukázat' na to, že Taliga nerešpektuje bežnú jazykovú prax a prirýchlo sa zbavuje pojmu zdôvodnenie. Keby sa namiesto toho pokúsil napríklad diferencovat' medzi jeho rozličnými druhmi a významami, azda by sa mohol vyhnút' rôznym nedorozumeniam a pripomienkam, aké boli predložené aj v tejto recenzii.

Akékolvvek pripomienky však nič nemenia na základnom hodnotení, že knižka Miloša Taligu predstavuje pozoruhodný a podnetný výklad kritického racionalizmu a metódy falzifikácie, ktorý možno všetkým záujemcom o túto tému vrelo odporučit'.

Martin Nuhlíček

Príspevok vznikol s podporou grantu VEGA SR č. 1/0258/2019 Realizmus a antirealizmus v súčasnej filozofii vedy.

Martin Nuhlíček

Katedra filozofie a dejín filozofie

Filozofická fakulta UK v Bratislave

Gondova 2, 81102 Bratislava

Slovenská republika

e-mail: martin.nuhlicek@uniba.sk

ORCID ID: https://orcid.org/0000-0002-7570-5318 